\title{
ANALISIS KANDUNGAN NITRAT DAN NITRIT SERTA TOTAL BAKTERI COLIFORM PADA AIR SUNGAI DI PT.SUCOFINDO SEMARANG
}

\author{
Iseh Muhammad Zaenal Afidin*, dan Kholidah \\ Jurusan Kimia, Fakultas Sains dan Teknologi, UIN Walisongo Semarang \\ Jl. Prof. Dr. Hamka, Tambakaji, Kec. Ngaliyan, Kota Semarang 50185. \\ "Email: isehkudus@gmail.com
}

\begin{abstract}
Abstrak
"Penelitian ini bertujuan untuk mengetahui kandunga nitrat dan itrit serta bakteri Coliform yang ada pada air sungai. Uji kandungan nitrat dan nitrit serta bakteri Coliform dilakukan di PT.Sucofindo Semarang. Uji kandungan nitrat dan nitrit mengikuti Prosedur SNI nomor 0669897.9-2011 dan 6989.9-2004 sedangkan uji total bakteri Coliform mengikuti prosedur SNI 93081-2010. Hasil uji nitrat menunjukan bahwa konsentrasi nitrat pada sempel yang diuji mencapai 1,32 $\mathrm{mg} / \mathrm{L}, 1,28 \mathrm{mg} / \mathrm{L}, 1,19 \mathrm{mg} / \mathrm{L}, 0,10 \mathrm{mg} / \mathrm{L}$, dan 0,12 $\mathrm{mg} / \mathrm{L}$ sehingga memenuhi peraturan Menteri Kesehatan Republik Indonesia Nomor : 416 / MENKES / PER/IX 1990,batas kandungan nitrat pada air yang dapat digunakan untuk kebutuhan sehari-hari adalah $10 \mathrm{mg} / \mathrm{L}$ sedangakan uji nitrit konsentrasi nitrit pada sampel satu, dua, dan tiga mencapai 0,13 mg/L , 0,1 mg/L , 0,22 mg/L sedangkan sampel empat dan lima mencapai 1,74 mg/L dan 1,64 mg/L sehingga sampel sampel satu, dua, dan tiga layak konsumsi sedangkan sempel empat dan lima tidak layak dikonsumsi menurut peraturan Menteri Kesehatan Republik Indonesia Nomor : 416 / MENKES / PER / IX 1990, batas kandungan Nitrit pada air yang dapat digunakan untuk kebutuhan sehari-hari adalah 1,0 mg/L. Hasil uji total bakteri Coliform pada sampel mencapai $4 \times 10^{2}-6 \times 10^{3} \mathrm{jml} / 100 \mathrm{~mL}$ sedangkan menurut peraturan Menteri Kesehatan Republik Indonesia Nomor : 416 / MENKES / PER / IX 1990,batas kandungan Total Coliform pada air per $100 \mathrm{~mL}$ yang dapat digunakan untuk kebutuhan sehari-hari adalah 50 jumlah/100 mL sehingga sampel yang diuji telah melewati batas maksimum dan tidak layak untuk dikonsumsi."
\end{abstract}

Kata kunci: Air,Air Sungai, Nitrat, Nitrit, Total Bakteri Coliform.

\section{PENDAHULUAN}

PT. Sucofindo merupakan perusahaan yang bergerak dalam bidang jasa inpeksi dan audit, pengujian dan analisis, sertifikasi, dan pelatihan dalam bidang pertanian, kehutanan, pertambangan (migas dan nonmigas), kontruksi, industri pengolahan, kelautan, perikanan, pemerintah, transportasi, sistem informatika dan energi terbarukan. Salah satu bidang jasa yang ada di PT. Sucofindo adalah pengujian dan anlisis mengenai kualitas air, air merupakan hal yang sangat penting di dalam kehidupan, semua makhluk hidup di dunia ini memerlukan air. Air bersih merupakan komponen yang penting bagi makhluk hidup untuk kelangsungan hidupnya, tumbuhan dan hewan sebagian besar tersusun dari air, sel tumbuhan mengandung 75\% air dan sel hewan mengandung $67 \%$. Manusia dalam menjalankan kegiatan sehari-hari tidak terlepas dari penggunaan air, seperti mencuci, memasak, mandi bahkan proses kerja tubuh dipengaruhi oleh air. Kebutuhan air bersih yang meningkat menjadi sesuatu yang terkadang sulit untuk didapatkan pada suatu daerah, menurut peraturan Menteri Kesehatan Nomor : 416/MEN.KES/PER/IX/1990 tentang syaratsyarat dan pengawasan kualitas air bahwa dalam meningkatkan derajat kesehataan masyarakat, perlu dilaksanakan pengawasan kualitas air secara intensif dan terus-menerus, serta kualitas air yang digunakan masyarakat harus memenuhi syarat kesehatan agar terhindar dari gangguan kesehatan.

Menurut peraturan Menteri Kesehatan Nomor : 416/MEN.KES/PER/IX/1990 tentang syarat-syarat dan pengawasan kualitas air. Air dikatakan tercemar apabila warna, rasa, baunya tidak seperti air bersih pada umumnya, salah satu sumber dari air bersih yang dapat digunakan untuk berbagai keperluan adalah air sungai,air sungai adalah air permukaan yang mengalir dipermukaan bumi.

Pada umummya air sungai mendapat pengotor tambahan selama pengalirannya, yang berasal dari limbah indutri, limbah rumah tangga, dan lain sebagainya, sehingga menimbulkan efek berupa gangguan kesehatan. Salah satu pengotor atau zat kimia yang perlu 
diwaspadai adalah kandungan nitrat dan nitrit serta total bakteri Coliform.

Nitrit merupakan bentuk nitrogen yang hanya sebagian teroksidasi, nitrit tidak ditemukan dalam air limbah yang segar melainkan ditemukan dalam air limbah yang sudah basi atau lama. Nitrit tidak dapat bertahan lama dan merupakan keadaan sementara proses oksidasi antara amoniak dan nitrat, nitrit bersumber dari bahan yang bersifat korosif yang banyak dipergunkana dalam perindustrian. Nitrit bersifat tidak tetap karena dapat dioksidasi menjadi nitrat dan dapat juga berubah menjadi amodniak (Ita Emilia, 2019).

Nitrat adalah senyawa yang dapat larut dalam air,senyawa ini merupakan bentuk senyawa nitrogen yang stabil, senyawa ini diperoleh melaui oksidasi yang sempurna senyawa nitrogen diperairan, keberadaan nitret pada sungai disebabkan karena adanya amonia yang bisa berasal dari alam sendri atau buangan dari manusia, adanya nitrat berlebih menyebabkan oksigen menjadi berkurang yang menyebabkan populasi ikan menurun, bau busuk, dan rasa air menjadi tidak enak.

Bakteri patogen yang mempengaruhi dari kualitas air menurut Kepmenkes yaitu bakteri Coliform seperti Eschercia Coli, Clostridium Pefringens, dan Salmonella bakteri, bakteri Coliform adalah golongan bakteri intestinal,yaitu hidup dalam saluran pencernaan manusia, bakteri ini adalah bakteri yang menjadi indikator keberadaan bakteri patogenik yang lain,penentuan Coliform menjadi indikator pencemaran karena jumlah dari koloninya akan berhubungan positif dengan keberadaan bakteri patogen yang lain yaitu E.coli, walaupuan E.Coli termasuk dalam bakteri normal saluran pencernaan akan tetapi saaat ini telah terbukti bahwa galur-galur tertentu mampu menyebabkan gastroenteritis sehingga apabila terdapat dalam air yang digunakan untuk sehari-hari maka akan menyiebabkan penyakit infeksius (Ita Emilia, 2019).

Penelitian ini dilakukan untuk mengetahui kandungan nitrat dan nitrit serta total bakteri Coliform air sungai sehingga dapat mengetahui kelayakan air sungai berdasarkan pada peraturan Menteri Kesehatan Nomor 416/MENKES/PER/IX 1990 tentang syaratsyarat dan pengawasan kualitas air.

\section{METODOLOGI}

Penelitian ini dilakukan untuk mengetahui kandungan nitrat dan nitrit serta total bakteri Coliform pada air sungai. Air sungai yang diuji tidak dapat disebutkan secara jelas karena merupakan rahasia perusahaan. Pengujian di lakukan di PT.Sucofindo Semarang.

\subsection{Alat}

Alat yang digunakan dalam penelitian ini adalah spektrometer UV-Vis HITACHI U2900, membran filter, manifold stainless Stell (pipa serap), pompa vakum, gelas erlenmeyer,cawan petri, pipet Ukur $50 \mathrm{~mL}, 10$ $\mathrm{mL}, 5 \mathrm{~mL}$, pipet gondok $10 \mathrm{~mL}, 5 \mathrm{~mL}$, neraca analitik AND GR 300, pinset, kertas saring, bunsen, membran filter, botol sampel, satu set kolom reduksi, autoklaf.

\subsection{Bahan}

Bahan yang digunakan dalam praktikum ini adalah Sampel Air Sungai alkohol 70\%, akuades, Cd granul, larutan Naphtyl Ethylene Diamine Dihidroklorida $\left(\mathrm{C}_{12} \mathrm{H}_{14} \mathrm{~N}_{2}\right)$, larutan Sulfanilamida $\left(\mathrm{C}_{6} \mathrm{H}_{8} \mathrm{~N}_{2} \mathrm{O}_{2} \mathrm{~S}\right)$, larutan bufer fosfat $\mathrm{Ph}$ 7.4, media $\mathrm{m}$ endo agar.

\subsection{Cara Kerja}

Cara kerja yang dilakukan mengikuti prosedur uji SNI nitrat dan nitrit serta total Coliform nomor 06-6989.9-2004 dan 6989.79-2011 serta nomor 9308-1 2010. Analisis Nitrat dilakukan dengan pembuatan Kurva Kalibrasi, dilakukan pengoptimalan alat uji spektrofotometer sesuai penggunaan alat untuk pengujian kadar nitrat.

Kedalam masaing-masing $25 \mathrm{~mL}$ larutan kerja tambahkan $75 \mathrm{~mL}$ larutan $\mathrm{NH}_{4} \mathrm{Cl}$ pekat lalu kocok. lewatkan larutan ke dalam kolom reduksi.Selanjutnya tampung dalam labu dilakukan pengkuran $100 \mathrm{~mL}$ larutan yang telah direduksi dan dimasukkan dalam labu ukur 100 mL. Tambahkan $1 \mathrm{~mL}$ pewarna (NED Dihidroklorida) dan $1 \mathrm{~mL}$ sulfanilamid .Baca absorbansinya dalam kisaran waktu antara 10 menit sampai 2 jam setelah penambahan larutan pewarna., membuat variasi konsentrasi 0,000 ppm, 0,010 ppm, 0,020 ppm, 0,050 ppm, 0,100 ppm, 0,150 ppm, 0,200 ppm, membuat kurva kalibrasi dengan mengukur absorbansinya pada panjang gelombang $543 \mathrm{~nm}$ dan tentukan persamaan garis lurusnya, jika koefisien korelasi regresi linier (r) lebih kecil 0,995, periksa kondisi alat dan ulangi langkah pembuatan kurva kalibrasi hingga diperoleh nilai koefisien $r \geq 0,995$.

Tahapan. Selanjutnya pengujian sempel uji Sampel, sempel air sungai diperoleh dari 
konsumen yang mengajukan uji dan analisi di PT. sucofindo Semarang. Sampel air sungai diambil sebanyak $500 \mathrm{~mL}$ dan letakkan dalam gelas erlenmeyer.sampel air sungai kemudian disaring dan ditampung dalam gelas erlenmeyer yang lain, perlakuan dilakukan hingga sampel air sungai menjadi bening, sampel air sungai yang telah bening kemudian diambil sebanyak $25 \mathrm{~mL}$ dan ditambahkan $75 \mathrm{~mL} \mathrm{NH}_{4} \mathrm{Cl}$, larutan sampel kemudian dimasukkan dalam kolom reduksi yang berisi $\mathrm{Cd}$ granul untuk diubah menjadi nitrit, Sampel ditampung dalam erlenmeyer, kemudian ditambahkan larutan NED dihidroklorida dan larutan saulfanilamid masing-masing sebanyak $1 \mathrm{~mL}$.

Selanjutnya diambil sampel sebanyak $100 \mathrm{~mL}$ tanpa melalui $\mathrm{Cd}$ granul kemudain ditambahkan NED dihidroklorida dan larutan sulfanilamida sebanyak masing-masing $1 \mathrm{~mL}$, dilakukan uji menggunakan Spektrometer UVVis (uji dilakukan sebanyak dua kali yaitu untuk sampel yang melalui Cd granul dan tanpa melalui Cd granul) dicatat absorbansinya dan konsentrasinya, Percobaan diulangi untuk sampel yang lain.

Tahap selanjunya adalah analisis nitritt, sampel air sungai diambil sebanyak $500 \mathrm{~mL}$ dan diletakkan dalam gelas erlenmeyer, sampel diambil sebanyak $100 \mathrm{~mL}$ dan diletakkan dalam labu ukur $100 \mathrm{~mL}$ ditambahkan ditambahkan NED dihidroklorida dan larutan sulfanilamida sebanyak masing-masing $1 \mathrm{~mL}$, dilakukan uji menggunakan Spektrometer UV-Vis dicatat absorbansinya dan konsentrasinya, percobaan diulangi untuk sampel yang lain, setelah itu dilakukan uji mikrobiologi, semua alat dan bahan dilakukan proses sterilisasi menggunakan autoklaf., akuades sebanyak $1000 \mathrm{~mL}$ yang telah steril kemudian ditambahkan $1,25 \mathrm{~mL}$ bufer fosfat. larutan akuades dibagi menjadi 10 masing-masing diambil sebanyak $100 \mathrm{~mL}$ kemudian diletakkan dalam botol, sampel diambil sebanyak $10 \mathrm{~mL}$ dengan menggunakan pipet ukur kemudian dilarutkan dengan $100 \mathrm{~mL}$ akuades yang telah ditambahkan bufer fosfat, dilakukan sebanyak dua kali pada botol $100 \mathrm{~mL}$ yang berbeda., membran filter disiapkan dan diletakkan dalam manifold stainless stell menggunkan pinset, dibilas menggunakan akuades steril sebnyak $50 \mathrm{~mL}$, kemudian pompa dihidupkan, setelah akuades steril habis kemudian sampel dituangkan dalam filter apparatus dan pompa kembali dihidupkan, setelah air pada sampel habis kemudian membran filter diambil dan diletakkan pada media $\mathrm{M}$ endo agar, percobaan diulangi untuk sampel yang lain, media $\mathrm{m}$ endo agar yang sudah siap kemudian diinkubasi selama 22 jam., jika bakteri tidak dapat dihitung maka dilakukan proses pengenceran dengan mengambil $10 \mathrm{ml}$ sempel dimasukkan dalam $100 \mathrm{ml}$ aquades yang telah ditambahkan buffer fosfat sesuai dengan cara kerja sebelumnya, Kemudian dilakukan penghitungan bakteri.

\subsection{Pengujian Statistik Kadar Nitrat dan Nitrit}

Analisa data yag digunakan untuk uji nitrat dan nitrit menggunakan persamaan sebagai berikut

Uji Nitrat

Konsentrasi $\mathrm{NO}_{3}=$ Konsentrasi $\mathrm{NO}_{3}-\mathrm{N}$

$\times\left(\mathrm{Mr} \mathrm{NO}{ }_{3} \times \mathrm{Ar} \mathrm{N}\right)$

Uji Nitrit

Konsentrasi $\mathrm{NO}_{3}=$ Konsentrasi $\mathrm{NO}_{3}-\mathrm{N}$

$\times\left(\mathrm{Mr} \mathrm{NO}{ }_{3} \times \mathrm{Ar} \mathrm{N}\right)$

\section{HASIL DAN PEMBAHASAN}

Analisis kandungan nitrat dan nitrirt serta kandungan total Coliform pada air sungai bertujuan untuk mengetahui kandungan nitrat dan nitrit serta total Coliform pada air sungai.

Tabel 1. Hasil Uji Nitrat Sempel Air Sungai

\begin{tabular}{ccc}
\hline $\begin{array}{c}\text { Larutan } \\
\text { Standard }\end{array}$ & Absorbansi & $\begin{array}{c}\text { Konsentrasi } \\
\text { Sempel } \\
\mathbf{m g} / \mathbf{L}\end{array}$ \\
\hline Standar 1 & 0.000 & 0.000 \\
Standar 2 & 0.036 & 0.010 \\
Standar 3 & 0.073 & 0.020 \\
Standar 4 & 0.186 & 0.050 \\
Standar 5 & 0.356 & 0.100 \\
Standar 6 & 0.354 & 0.150 \\
Standar 7 & 0.708 & 0.200 \\
\hline
\end{tabular}

Tabel 1 meupakan hasil uji larutan standar, larutan uji tersebut kemudian digunakan untuk membuat kurva standar dan ditentukan nilai r. Larutan standar digunakan untuk uji konsentrasi nitrat dan nitrit pada air sungai, pembuatan larutan standar ini mengetahui konsentrasi dari sempel yang diuji. 


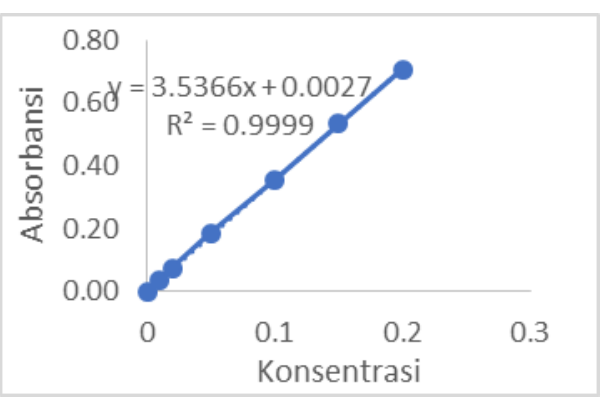

Gambar 1. Grafik kurva standar uji nitrat dan nitrit sempel air sungai

Tabel 2. Hasil Uji Nitrat Sempel Air Sungai

\begin{tabular}{lccc}
\hline $\begin{array}{c}\text { Sempel } \\
\text { air } \\
\text { sungai }\end{array}$ & $\begin{array}{c}\text { Absorban } \\
\text { si }\end{array}$ & $\begin{array}{c}\text { Konsentrasi } \\
\text { Sempel mg/L }\end{array}$ & $\begin{array}{c}\text { Pengencera } \\
\text { n }\end{array}$ \\
\hline $\begin{array}{l}\text { Sempel } \\
1\end{array}$ & 0.292 & 0.08 & 10 \\
$\begin{array}{l}\text { Sempel } \\
2\end{array}$ & 0.291 & 0.08 & 10 \\
Sempel & 0.236 & 0.07 & 10 \\
3 & & & \\
$\begin{array}{l}\text { Sempel } \\
4\end{array}$ & 0.01 & 0.003 & 10 \\
$\begin{array}{l}\text { Sempel } \\
5\end{array}$ & 0.012 & 0.003 & 10 \\
\hline
\end{tabular}

\section{Tabel 3. Hasil Uji Nitrat Sempel Air Sungai}

\begin{tabular}{cccc}
$\begin{array}{c}\text { Hasil } \\
\mathbf{N O}_{2} \\
\text { melalui } \\
\text { kolom } \\
\text { reduksi } \\
\text { mg/L }\end{array}$ & $\begin{array}{c}\text { Hasil } \\
\mathbf{N O}_{2} \\
\text { tanpa } \\
\text { melalui } \\
\text { kolom } \\
\text { reduksi } \\
\text { mg/L }\end{array}$ & $\begin{array}{c}\text { Konsentrasi } \\
\mathbf{N O}_{3}-\mathbf{L} \text { mg/L } \\
(\mathbf{a}-\mathbf{L})\end{array}$ & $\begin{array}{c}\text { Konsentrasi } \\
\mathbf{N O}_{3} \mathbf{m g} / \mathrm{L}\end{array}$ \\
\hline 0.8 & 0.53 & & \\
0.8 & 0.51 & 0.27 & \\
0.7 & 0.4 & 0.3 & 1.19 \\
0.03 & 0.007 & 0.023 & 1.28 \\
0.03 & 0.004 & 0.026 & 0.10 \\
\hline
\end{tabular}

Tabel 2 dan 3 merupakan hasil uji nitrat pada sempel air sungai di PT.Sucofindo semarang. Dari hasil diatas diperoleh Dari data diatas diketahui bahwa konsentrasi dari nitrat pada sampel semua sempel yang diuji tidak tercemar atau memenuhi peraturan Menteri Kesehatan Republik Indonesia Nomor : 416 / MENKES / PER/IX 1990,batas kandungan Nitrat pada air yang dapat digunakan untuk kebutuhan sehari-hari adalah $10 \mathrm{mg} / \mathrm{L}$.
Tabel 3. Hasil uji Nitrit Sempel Air Sungai

\begin{tabular}{lccc}
\hline $\begin{array}{c}\text { Sempe } \\
\mathbf{l} \text { air } \\
\text { Sungai }\end{array}$ & $\begin{array}{c}\text { Absorbans } \\
\mathbf{i}\end{array}$ & $\begin{array}{c}\text { Konsentras } \\
\text { i Sempel } \\
\mathbf{m g} / \mathbf{L}\end{array}$ & $\begin{array}{c}\text { Pengencera } \\
\mathbf{n}\end{array}$ \\
\hline $\begin{array}{l}\text { Sempel } \\
1\end{array}$ & 0.024 & 0.007 & 10 \\
$\begin{array}{l}\text { Sempel } \\
2\end{array}$ & 0.013 & 0.003 & 10 \\
$\begin{array}{l}\text { Sempel } \\
3\end{array}$ & 0.139 & 0.0039 & 10 \\
$\begin{array}{l}\text { Sempel } \\
4\end{array}$ & 0.188 & 0.053 & 10 \\
Sempel & 0.179 & 0.05 & 10 \\
5 & & & \\
\hline
\end{tabular}

Tabel 4. Hasil Uji Nitrit Sempel Air Sungai

\begin{tabular}{cc}
$\begin{array}{c}\text { Konsentrasi } \\
\mathbf{N O}_{2}-\mathbf{N}\end{array}$ & $\begin{array}{c}\text { Konsentrasi } \\
\mathbf{N O}_{2} \mathbf{~ m g} / \mathbf{L}\end{array}$ \\
\hline 0.07 & 0.22 \\
0.03 & 0.1 \\
0.039 & 0.13 \\
0.53 & 1.74 \\
0.5 & 1.64 \\
\hline
\end{tabular}

Dari tabel 3 dan 4diketahui bahwa kualitas air sungai untuk sampel satu, dua, dan tiga layak konsumsi sedangkan sempel empat dan lima tidak layak dikonsumsi menurut peraturan Menteri Kesehatan Republik Indonesia Nomor : 416 / MENKES / PER / IX 1990, batas kandungan Nitrit pada air yang dapat digunakan untuk kebutuhan sehari-hari adalah 1,0 mg/L.

Terdapat perbedaan prosedur pengujian $u$ ntuk uji nitrat dan nitrit, pengujian nitrat akan melalui kolom reduksi yang berisi $\mathrm{Cd}$ granul yang berfungsi untuk mengubah nitrat menjadi nitrit.

\section{Tabel 5. Uji Total Coliform}

\begin{tabular}{cc}
$\begin{array}{c}\text { Sampel Air } \\
\text { Sungai }\end{array}$ & $\begin{array}{c}\text { Total } \\
\text { Coliform } \\
\text { jumlah/100 } \\
\text { mL }\end{array}$ \\
\hline Sampel 1 & $6 \times 10^{2}$ \\
Sampel 2 & $4 \times 10^{2}$ \\
Sampel 3 & $3.9 \times 10^{3}$ \\
Sampel 4 & $6 \times 10^{3}$ \\
Sampel 5 & $6 \times 10^{2}$ \\
\hline
\end{tabular}

Tabel 5 menunjukan uji total bakteri Coliform pada sempel air sungai, menurut peraturan Menteri Kesehatan Republik Indonesia Nomor : 416 / MENKES / PER / IX 1990,batas kandungan Total Coliform pada air per $100 \mathrm{~mL}$ yang dapat digunakan untuk kebutuhan sehari-hari adalah 50 jumlah/100 $\mathrm{mL}$. Sampel yang diuji telah melewati batas maksimum sehingga tidak layak untuk dikonsumsi. 


\section{KESIMPULAN}

Dari penelitian yang telah dilakukan dapat disimpulkan bahwa :

1. Hasil uji nitrat menunjukan bahwa konsentrasi nitrat pada sempel yang diuji mencapai $1,32 \mathrm{mg} / \mathrm{L}, 1,28 \mathrm{mg} / \mathrm{L}, 1,19$ $\mathrm{mg} / \mathrm{L}, 0,10 \mathrm{mg} / \mathrm{L}$, dan $0,12 \mathrm{mg} / \mathrm{L}$ sehingga memenuhi peraturan Menteri Kesehatan Republik Indonesia Nomor : 416 / MENKES / PER/IX 1990,batas kandungan nitrat pada air yang dapat digunakan untuk kebutuhan sehari-hari adalah $10 \mathrm{mg} / \mathrm{L}$ sedangakan uji nitrit konsentrasi nitrit pada sampel satu, dua, dan tiga mencapai $0,13 \mathrm{mg} / \mathrm{L}, 0,1 \mathrm{mg} / \mathrm{L}, 0,22 \mathrm{mg} / \mathrm{L}$ sedangkan sampel empat dan lima mencapai $1,74 \mathrm{mg} / \mathrm{L}$ dan $1,64 \mathrm{mg} / \mathrm{L}$ sehingga sampel sampel satu, dua, dan tiga layak konsumsi sedangkan sempel empat dan lima tidak layak dikonsumsi menurut peraturan Menteri Kesehatan Republik Indonesia Nomor : 416 / MENKES / PER / IX 1990, batas kandungan Nitrit pada air yang dapat digunakan untuk kebutuhan sehari-hari adalah $1,0 \mathrm{mg} / \mathrm{L}$.

2. Hasil uji total bakteri Coliform pada sampel mencapai $4 \times 10^{2}-6 \times 10^{3} \mathrm{jml} / 100 \mathrm{~mL}$ sedangkan menurut peraturan Menteri Kesehatan Republik Indonesia Nomor : 416 / MENKES / PER / IX 1990,batas kandungan Total Coliform pada air per 100 $\mathrm{mL}$ yang dapat digunakan untuk kebutuhan sehari-hari adalah 50 jumlah/100 $\mathrm{mL}$ sehingga sampel yang diuji telah melewati batas maksimum dan tidak layak untuk dikonsumsi

\section{DAFTAR PUSTAKA}

Emilia, I. (2019) 'Analisa Kandungan Nitrat dan Nitrit dalam Air Minum Isi Ulang Menggunakan Metode Spektofotometri UVVis Ita Emilia', Jurnal Indobiosains, 1(1), pp. 38-44.

Badan Standardisasi Nasional (2004) 'SNI 066989.9-2004 Air dan air limbah - Bagian 14: Cara uji nitrit (NO2-N) secara spektrofotometri', (2), p. 13.

Badan Standardisasi Nasional (2011) 'SNI 6989.79:2011 Air dan air limbah - Bagian 79: Cara uji nitrat(NO3-N) dengan spektrofotometer UV-visible secara reduksi kadmium', (3), p. 15.

Badan Standardisasi Nasional (2010) 'SNI ISO 930801-2010 Kualitas Air - Deteksi dan penghitungan bakteri coliform dan Eschercia coli Bagian 1 : Metode filtrasi dengan membran',.
Indonesia, M. K. R. (1976) 'Peraturan Menteri KesehatanNomor :416/MEN.KES/PER/IX/1 990 Tentang Syarat-Syarat dan Pengawasan Kualitas Air', 72, pp. 227-256. doi: 10.1007/978-1-4684-0955-0_19.

PT. Sucofindo. 'Sejarah Sigkat Sucofindo'. www.sucofindo.co.id.

(Accesed : 01 Januari 2020). 